\title{
SPECIFICS OF ANALYSIS OF COMPANIES OPERATING IN THE DIGITAL ECONOMY
}

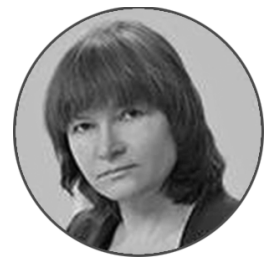

Article history:

Received 18 January 2018 Received in revised form 26 January 2018

Accepted 9 February 2018

Translated 16 April 2018

Available online 27 June 2018

JEL classification: G30, G32
Vera G. KOGDENKO

National Research Nuclear University MEPhl, Moscow, Russian Federation

kogdenk07@mail.ru
Conclusions and Relevance The proposed methodology helps assess corporate operations in the digital economy economy

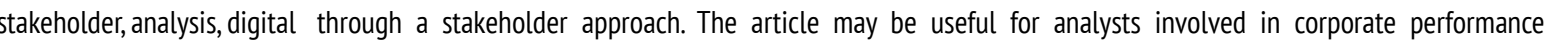

Abstract

Importance The article analyzes companies operating in the quaternary sector of the economy (digital economy). Objectives The study aims to investigate the specifics of companies operating in the digital economy and to develop proposals for improving their analysis.

Methods The methodology of the study rests on the stakeholder theory and resource-based approach to organizational analysis.

Results I developed a methodology that is in sync with the specifics of companies operating in the quaternary sector of the economy. It includes seven steps. At the first step, corporate competitive advantages are assessed. At the second step, risks generated by key stakeholders are analyzed, including those associated with intellectual capital and social and reputation capital. At the third step, intellectual capital is examined, followed by social and reputation capital and its four components. At the fifth step, company's cash flows and financial solvency are estimated; at the sixth step, efficiency of investment activities is evaluated on the basis of cash flows from operations and financing. At the final step of the analysis, value drivers that relate directly to intellectual capital and social and reputation capital, and company's intrinsic value are estimated.

appraisal using integrated reporting.
\end{abstract}

The editor-in-charge of this article was Irina M. Vechkanova Authorized translation by Irina M. Vechkanova

Business analysis gets more refined and sophisticated as the information society and quarternary sector of the economy evolve and rapid changes occur in the business environment. The developments below had the most significant effect on the economy:

- growing external threats and closer relationship of entities with the business environment. According to M. Reeves, S. Levin, D. Ueda [1], this puts business at higher stake and reduces its life cycle. The average life

${ }^{\dagger}$ For the source article, please refer to: Когденко В.Г. Особенности анализа компаний цифровой экономики. Экономический анализ: теория и практика. 2018. Т. 17. № 3. С. 424-438.

URL: https://doi.org/10.24891/ea.17.3.424 expectancy of S\&P 500 companies fell from 67 years in the 1920s down to 15 years nowadays [2];

- rearrangement of the business goal setting process, abandonment of the proprietary concept and adoption of the stakeholder value creation concept, as some Western and Russian researchers put it (R.E. Freeman [3], J.E. Post, L.E. Preston, S Sachs [4], I.V. Ivashkovskaya $[5,6])$. It is the focus on stakeholders' interests that enables businesses reinforce their position, ensure sustainability and resist to external challenges;

- transition from traditional linear technologies to information-based ones, from physical to information 
substratum [2] throughout all the sectors of the economy, thus driving business from the diminishing return to the accelerating one;

- the use of Big Data for analysis and forecasting through predictive mathematical models, and identification of correlations to comprehend the business environment and behavior of economic agents [7];

- the use of the blockchain technology in the nearest future to register titles for analyzable items [8], thus making the analysis more prompt and reliable.

In addition to overall changes in the economy, the analysis should also be sensitive to distinctions of entities operating in the quarternary sector of the economy as they create and use databases and information resources, develop computer-assisted software:

- new business approaches studied by M. Malone, S. Ismail, Y. Van Geest - increased business mobility in all aspects, i.e. recruitment of temporary staff, independence on tangible assets, use of third party assets, crowdsourcing, crowdfunding, crowdlending, crowdinvesting, outsourcing [2];

- modification of the asset mix, i.e. a decrease in tangible production assets, increase in a percentage of intangible assets. The prevalence of knowledge-based (including digitized), social and reputation capital;

- change in expenditures, i.e. a decrease in tangible costs, increase in the percentage of costs for personnel, rent, IT services, etc. Expenditures feature a rise in fixed expenses, thus raising the operational leverage and profit volatility;

- continuous business renewal, material investment in business development since the sector tends to experience rapid changes in technology, consumer preferences, business model.

It is difficult to use traditional financial bases, such as non-current assets, total assets, equity and invested capital for analysis due to distinctions of the quarternary sector companies, since value of the assets is too volatile. Hence traditional indicators of financial sustainability, liquidity, turnover and profitability are no longer meaningful for information economy businesses. The analysis is now based on more reliable metrics, such as cash flows and respective indicators. Researchers emphasized the advantage of analytical indicators based on cash flow [9].

Therefore, business distinctions determine the specifics of analysis. To devise techniques for the analysis (Fig. 1), publicly available data of the Russian companies in the analyzable sector were used, i.e. Yandex' ${ }^{1}$, Mail.Ru Group ${ }^{2}$, International Integrated Reporting Framework ${ }^{3}$, Sustainability Reporting Guidelines ${ }^{4}$, WICI materials (World Intellectual Capital Initiative) ${ }^{5}$, in particular, Guidance for Integrated Corporate Disclosure ${ }^{6}$.

Step 1. Analysis of Corporate Competitiveness. At this step, certain aspects of strategic SPACE-analysis are conducted to evaluate the sector development indicators, external stability factors and competitive advantages of the entity. The analysis involves sectoral data and data of benchmark identical companies, which are stored in information resources, like SPARK Interfax, for instance?.

Coefficients of variation are gauged to evaluate the stability of the environment. They are measured against absolute values of the entity, its counterparts, sectoral indicators:

$$
k=\frac{\sigma}{\bar{x}} \text {, }
$$

where $\bar{x}$ is the expected mean of indicators;

$\sigma$ is the root mean square deviation of the indicator measured with the following formula:

\footnotetext{
${ }^{1}$ Yandex. Disclosure. URL: https://yandex.ru/company/prospectus/ (In Russ.)

${ }^{2}$ Mail.Ru Group. Financial Reports. URL: https://corp.mail.ru/ru/investors/reports/

${ }^{3}$ International Integrated Reporting Framework. URL: http://integratedreporting.org/wp-content/uploads/2015/03/13-1208-THE-INTERNATIONAL-IR-FRAMEWORK-2-1.pdf

${ }^{4}$ Sustainability Reporting Guidelines. URL: https://www.globalreporting.org/resourcelibrary/G3.1-GuidelinesIncl-Technical-Protocol.pdf

${ }^{5} \mathrm{WICl}$ - the World's Business Reporting Network. URL: http://www.wici-global.com/wpcontent/uploads/2012/06/Updated-Brochure-WICI.pdf

${ }^{6}$ Guidance for Integrated Corporate Disclosure and CompanyInvestor Dialogue for Collaborative Value Creation. May 29, 2017. URL: http://www.meti.go.jp/english/press/2017/pdf/0529_ 004b.pdf

${ }^{7}$ SPARK. URL: http://www.spark-interfax.ru/
} 


$$
\sigma=\sqrt{\frac{\sum\left(x_{n}-\bar{x}\right)^{2}}{n-1}},
$$

where $x_{n}$ is the value of the indicator in the $n$-period of time.

The following criteria can be used to evaluate the coefficient of variation and substantiate a conclusion on the stability of the environment. Below $10 \%$ is high stability; $10-20 \%$ is the average stability of the environment; below $20 \%$ is low stability.

Relative and absolute market shares are analyzed to substantiate conclusions on competitive advantages of an entity. Growing indicators signify that the entity strengthens its market position:

$S_{A}=T R / T R_{A} ;$

$S_{M}=T R / T R_{M}$

where $S_{A} S_{M}$ are relative and absolute market shares of the entity respectively;

$T R$ is revenue of the entity;

$T R_{A}$ is revenue of the benchmark entity;

$T R_{M}$ is market capacity.

Afterwards long-term trends in key corporate metrics are evaluated through the average exponential growth rates. In comparison with the sectoral dynamics and indicators of the benchmark entity, it allows to evaluate the competitive advantage of business:

$$
r=\left(\frac{x_{n}}{x_{0}}\right)^{\frac{1}{n}}-1,
$$

where $x_{0}, x_{n}$ indicate the baseline and $n$-year respectively.

The entity is deemed to have any competitive advantage if it outperforms its counterparts and sector in terms of growth rates. However, considering the rapidity of changes in the environment, advantages of previous periods cannot be a precursor of the same in the future.

Long-term growth rates are mutually compared to evaluate corporate strategic performance in the long run. If revenue and proceeds grow faster than assets, this means the entity carries out investing activities and uses its assets more productively. If net cash flow from operating activity outgrows proceeds and revenue, this signifies that expenditures and working capital are managed effectively in the analyzable period.

The first step reveals the stability level of the business environment, strategic effectiveness of the entity and its competitive advantage, if any.

Step 2. Risk Assessment in Entities Operating in the Digital Economy. Assessing the risk, it is important to remember that some risks are common no matter which sector an entity operates in [10], while the other are specific to a certain sector. The first group refers to risks associated with key stakeholders and capital they provide:

- controlling shareholders and top executives contribute to the organizational wealth meaning the knowledge of systems, procedures and protocols ${ }^{8}$. They are exposed to strategic risk and abuse risk";

- shareholders and creditors provide financial capital triggering liquidity risks ${ }^{10}$, currency risk, interest rate risk, risk of limited access to capital;

- buyers generate the social and reputation capital, its market component, which relates to the reputational, market and credit risks;

- competitors and business partners create the social and reputation capital from perspectives of the market. Their actions may raise business and market risks;

- the State and the public create the social and reputation capital from social perspectives. They inflict country and regional risks, legal risk, social license risk.

Specific risks of entities operating in the information economy mainly affect those types of capital, which are fundamental for them, i.e. intellectual and reputation capital. What distinguishes these types of capital is that they proceed from a wide array of stakeholders, including external ones, i.e. consumers, business partners, society, governmental authorities, and

\footnotetext{
${ }^{8}$ International Integrated Reporting Framework. URL: http://integratedreporting.org/wp-content/uploads/2015/03/13-1208-THE-INTERNATIONAL-IR-FRAMEWORK-2-1.pdf

${ }^{9}$ Pronouncement of the RF Ministry of Finance № П3-11/2013 Setting Up and Implementing the Internal Control by the Business Entity over Business Facts, Accounting and Financial Reporting.

${ }^{10}$ Pronouncement of the RF Ministry of Finance № П3-9/2012 On Disclosure on Business Risks in Annual Financial Statements.
} 
internal ones, i.e. shareholders, managers, personnel (suppliers of intellectual capital). Hence the risks are linked with the types of capital, rather than with stakeholders.

Intellectual capital, including the digital one, is exposed to risks below [11]:

- risk of innovation generation and acquisition;

- risk of key management, personnel who are capable of generating innovation, inability to recruit innovating talent;

- risk of Internet infrastructure accessibility, development and servicing;

- risk of intellectual capital value;

- risk of intellectual property protection.

The social and reputation capital is exposed to the following risks:

- risk of brand value, inability to maintain and improve the brand;

- reputational risk in relation to a wide array of shareholders;

- risk associated with cybercrime affecting the corporate image, risk of unauthorized use of intellectual property and consumers' personal data.

The analysis thus assesses and evaluates risks of the analyzable entity and determines the efficiency of the methods to manage them.

Step 3. Intellectual Capital Analysis. Fig. 2 depicts components of intellectual capital pertaining to the digital economy's companies. As the intellectual capital quickly lose value, innovation generation indicators become instrumental for analyzing it since innovation creates and stimulates the organizational wealth.

The analysis of the organizational wealth, which is included into the intellectual capital of the digital economy's capital, is subdivided into following interim steps:

- analysis of the innovation generation system, i.e. methods for acquiring, creating, procuring from third parties or borrowing innovation. Depending on the methods, there exist innovation generating companies, which create innovation on their own; directing companies, which order R\&D from other parties; replicating companies, which copy innovation; companies acquiring innovative businesses;

- analysis of uncontrolled knowledge transformation methods. Depending on the type of knowledge, there exist codification methods based on the wide use of IT, and personalization of knowledge, which underlie the knowledge that is hard to codify.

Being the second component of intellectual capital, intellectual property is analyzed as follows:

- analysis of the composition and value of available intellectual property items. In case of the analyzable sector, software and databases are concerned;

- analysis of R\&D expenditures by segment, estimation of innovation acquisition costs and their effectiveness;

- analysis of movements and condition of intellectual property items, which involves how often items are purchased and disposed of, their wear and tear measured by value indicators;

- analysis of a percentage of innovative products (services) within corporate revenue.

Reliable information on intellectual property items is crucial for purposes of intellectual property analysis. The rapidly growing blockchain technology will help solve this issue in the future. Being a tool to store transaction details, databases as publicly available blocks of information, this technology enables users to do the following [8]:

- confirm the title for intellectual property items;

- register intellectual property items (services of virtual notaries public);

- protect intellectual property items;

- make standardized transactions with intellectual property.

According to some researchers, M. Swan, for instance [8], the blockchain technology will dramatically change the relationship among agents interact, management of intellectual property item, access to them and entitlement for them.

Currently, entities are unable to create innovation internally using only their own resources. They need to share knowledge and attract new talent and knowledge 
all the time. Ongoing staff rotation, recruitment of new talent, who possess new knowledge and ideas, signal inter alia the ability to generate intellectual capital. The processes are gauged with the number of open vacancies. Rates of staff recruitment, attrition and turnover, which includes those employees who quit due to undesirable reasons, i.e. voluntary quitting or labor misconduct, unlike the attrition. High turnover against low attrition rates signifies an influx of new knowledge to the entity.

At this step of analysis, intellectual capital is assessed and evaluated, with the efficiency of this capital generation processes being reviewed as well.

Step 4. Analysis of Social and Reputation Capital. Fig. 3 displays components of the social and reputation capital and estimates. Key aspects of the social and reputation capital analysis concern the corporate reputation among a wide array of stakeholders, methods to communicate with them so as to pump new knowledge and ideas into the entity, and investments the entity makes in its brand and stakeholders' loyalty ${ }^{11}$. Gleaning the outer exuberance and converting it into the intrinsic value, as experts put it, interfaces become a key communication channel with external stakeholders [2].

What really matters to form and develop the social and reputation capital is create the open environment based on transparency and trust [2], which is difficult to evaluate through published reports. As its crucial aspect with respect to the social and reputation capital, the analysis applies to the brand, its value indicators, trademarks, applications for trademarks, their quality and quantity, including the extent to which they influence the entity's competitive advantage, market position and barriers for other entities.

It is also important to consider factors eroding stakeholders' confidence. These issues were studied by A. Zaman [12]. In case of the analyzable sector, various types of the social and reputation capital are affected by the following factors:

1) factors destroying the capital in relationship with consumers:

- non-existent innovation;

\footnotetext{
${ }^{11}$ Guidance for Integrated Corporate Disclosure and CompanyInvestor Dialogue for Collaborative Value Creation. May 29, 2017. URL: http://www.meti.go.jp/english/press/2017/pdf/0529_004b.pdf
}

- brand failure, negative feedback, negative publicity;

- inadequacy of the system, communication with consumers;

- ineffective interface;

- insufficient qualification of personnel and inappropriate servicing;

2) factors destroying the capital in relationship with the society:

- difficulties in regulatory compliance;

- difficulties in data protection;

- violation of the code of ethics;

3) factors destroying the capital in relationship with the personnel and shareholders:

- violation of the minority shareholders' rights;

- implementation of the personalized policy;

- non-transparent activity, dual standards of corporate policy, mismatch of the management's actions and corporate values;

- financial losses and fraud.

This step of the social and reputation analysis identifies its quality, quantity and factors for its creation and destruction.

Step 5. Analysis of Cash Flows as Part of the Stakeholder Approach. As mentioned above, cash flows of the digital economy's businesses lay the reliable financial basis to estimate analytical indicators, such as:

- corporate solvency and liquidity;

- allocation of value created;

- effectiveness and intensity of investing activity;

- intrinsic value.

Assessing the liquidity and solvency, it is necessary to consider the following aspects. Reducing working capital and inaccurate estimates of balance sheet items distorts liquidity indicators assessed through the balance sheet. High liquidity indicators can be regarded as inefficient management of working capital. Furthermore, as estimated value of total assets is volatile and inaccurate, traditional metrics of capital structure and equity-to-asset ratio, in particular, 
financial sustainability become irrelevant. Cash-flowbased indicators and liabilities seem to be more reliable. First of all, it is worth mentioning the Beaver ratio measured as net cash flow from operating activity to total liabilities. It reflects the financial coverage of the debt:

$k_{B}=N C F_{O} / L$,

where $N C F_{0}$ is net cash flow from operating activity;

$L$ is total liabilities.

$k_{D}=N C F_{O} / C L$,

where $C L$ stands for current liabilities.

Similar principles underlie coverage ratios, which give a good view of corporate financial sustainability. For example, interest coverage ratio shows to what extent cash flow from operating activity exceeds interests paid:

$k_{l}=C F_{O} / F C$,

where $C F_{O}$ is cash flow from operating activity before interest and taxes;

FC refers to interests paid.

As part of the stakeholder approach, it is critical to evaluate the way cash flows are distributed among stakeholders. To do so, as part of the resource-based approach, resource intensity of cash flows is determined as the ratio of payments to stakeholders for resources to total proceeds. The algorithm is compliant with Sustainability Reporting Guidelines ${ }^{12}$, which is to be followed to study the economic value. As part of the analysis, the following payments are examined:

- payroll payments;

- payments to providers of intangible assets;

- payments to owners of companies upon acquisition of control over them;

- payment to providers of productive capital items;

- taxes and social security charges to governmental authorities social security funds;

- dividends to shareholders and payments for shares purchased;

- principal and interests paid to creditors;

\footnotetext{
${ }^{12}$ Sustainability Reporting Guidelines.

URL: https://www.globalreporting.org/resourcelibrary/G3.1-GuidelinesIncl-Technical-Protocol.pdf
}

- payments for social programs and charity to public organizations.

Resource intensity is measured with the formula, the denominator of which makes an amount of cash flows from all types of activity and opening balance of cash and cash equivalents:

$R / I_{1}=P_{i} / R$

where $P_{i}$ refers to payments made in favor of the $i$-group of stakeholders;

$R$ represents total cash flows from operating, investing and financial activity and opening balance of cash.

Unlike those resource intensity indicators presented in proceedings by O.V. Efimova [13], N.P. Lyubushin [14] and measured as the ratio of expenses to revenue, I suggest calculating the same on the basis of cash flows. The algorithm allows to assess the resource intensity with respect to payments as part of investing and financial activity, while computations based on expenditures focus on operating activity only.

At this step of the analysis, computations reveal corporate financial sustainability and its major stakeholders, who are beneficiaries in such cases.

Step 6. Evaluation of Investing Activity. Considering the rapid pace of changes in the economy, there should be a continuous flow of innovation and investment, which is a cornerstone for business survival and development. Hence it is crucial to evaluate the investing activity of the company as part of its financial analysis.

The mix of investments is suggested to be evaluated through a percentage of payments made to providers of intangible assets, owners of companies once control over them is assumed, providers of productive capital items. Investment in intangible types of capital turns to be most difficult since it is often attributed to current expenses. As the $\mathrm{WICl}$ experts note, businesses' inability to recognize and assess investment in intangible assets impedes the effective allocation of resources ${ }^{13}$.

The ratio of negative net cash flow from investing activity to cash flow from operating one shall be analyzed to evaluate the former. The 20-percent ratio

\footnotetext{
${ }^{13}$ Guidance for Integrated Corporate Disclosure and CompanyInvestor Dialogue for Collaborative Value Creation. May 29, 2017. URL: http://www.meti.go.jp/english/press/2017/pdf/0529_ 004b.pdf
} 
means highly intensive investing activity. It is also important to compare net cash flow from operating, investing and financial activities. If business is effective, carrying out the sustainable investing activity, there should be an equilibrium among the three types of activities, given the balance of cash remains unchanged. This is due to the fact that the negative balance of investing activity is financed with the positive balance from operating and current activities:

$N C F_{1}=N C F_{O}+N C F_{F_{1}}$

where $N \mathrm{NF}_{\text {l, }} N C F_{0}, N C F_{F}$ stand for net cash flow from investing, operating and financial activities respectively.

The modified internal rate of return is suggested to be used in order to assess the effectiveness of investing activity. As part of this approach, the entity is viewed as a portfolio of investment projects, with the computation being based on cash flow indicators. Net cash flow from operating activity is regarded as the result of investment, while net cash flow from investing activity is considered as investment. The following formula is used:

$$
M I R R=\left(\frac{\sum_{i=1}^{I} C F B I_{O i}(1+r)^{I-i}}{N C F_{I i}(1+d)^{-i}}\right)^{\frac{1}{I-1}}-1
$$

where $\mathrm{CFBI}_{\mathrm{O}}$ is net cash flow from operating activity before interests in the $i$-year;

$N C F_{l i}$ is net cash flow from investing activity in the $i$-year;

$r$ is a reinvestment rate;

$d$ is a discount rate.

This indicator can be construed as the return on invested capital for the past period of time (4 to 5 years). The calculation algorithm is appropriate in case of cash flow from the return on investment CFROI, however it still differs in a way. For example, the initial amount of investment is not assessed to modify the internal rate of return, but cash flow from investment is measured. The following difficulties arise from evaluating the efficiency of investment in intangible types of capital:

- difficulty in segregating cash flows from operating and investment activity. For example, investment in the intellectual capital and social and reputation capital is often recognized as current expenses. However, the combination of the cash flows will not distort the result if the modified internal rate of return is applied;

- difficulty in substantiating the discount rate and reinvestment rate. The discount rate shall mean weighted average cost of capital for the previous accounting period. The reinvestment rate shall be understood as weighted average cost of capital since the return on investment is impossible to be correctly assessed due to volatility of the cost of invested capital.

This step of the analysis makes a breakdown of investment and characterizes the intensity and effectiveness of investing activity for the analyzable period.

Step 7. Analysis of Value Drivers and Estimation of Intrinsic Value. Generated by key types of capital, such as organizational wealth, intellectual property, social and reputation capital, the respective factors are of the highest significance for the value of companies operating in the quarternary sector of the economy.

Please find below value drivers generated by organizational wealth:

- increasing rapidity of data processing and transfer, incentives for innovation acquisition, creation of intellectual property through ongoing market monitoring and identification of emerging innovation;

- increased efficiency of technology for knowledge codification and creation of intellectual property;

- more robust technologies for data personalization and creation of the social and reputation capital.

Intellectual property is a pipeline of Science \& Technology rent:

- by infusing more innovation of products and services, generating new services, expanding their portfolio, improving the market appeal, quality, competitiveness;

- by increasing sales volume and market share through sustainable technologies and better use of assets;

- by reducing the resource intensity of products and production costs as a result of sustainable technologies. 
The corporate component of the social and reputation capital influences the intrinsic value since it helps in the following tasks:

- it creates the corporate environment encouraging the staff for new innovation;

- it constantly attracts new talent, various stakeholders who stream innovation into the business.

The market component of the social and reputation capital is intended for:

- benchmarking, search for new ideas in the market, outsourcing of ideas;

- raising consumer loyalty, making sales less volatile;

- fueling innovation through an exchange of information with counterparts.

The social component of the social and reputation capital is designated to:

- ensure accessibility, development and maintenance of the Internet infrastructure;

- involve public and social institutions to support business development.
As a conclusion, it is reasonable to evaluate the intrinsic value of the entity (its invested capital) through cash flows:

$$
V_{I C}=\frac{\left(C F B I_{O}-N C F_{I}\right)(1+g)}{d-g},
$$

where $g$ is sustainable growth.

This formula embodies the fact that the intrinsic value is measured as an excess of the entity's cash flow from operating activity over that from investing one, possibilities for its growth, and discount rate.

The stakeholder approach becomes a cornerstone for evaluating the performance of entities in the digital economy. It is crucial to analyze intellectual capital and social and reputation capital and evaluate the investing activity. The framework for financial data relies upon cash flows, which determine the effectiveness of operating activity, intensity and efficiency of investing activity, ability to perform financial obligations. At this step, the intrinsic value is assessed, thus shedding light onto the current position of business and look into its future.

\section{Figure 1}

The scheme for analyzing the digital economy's entities

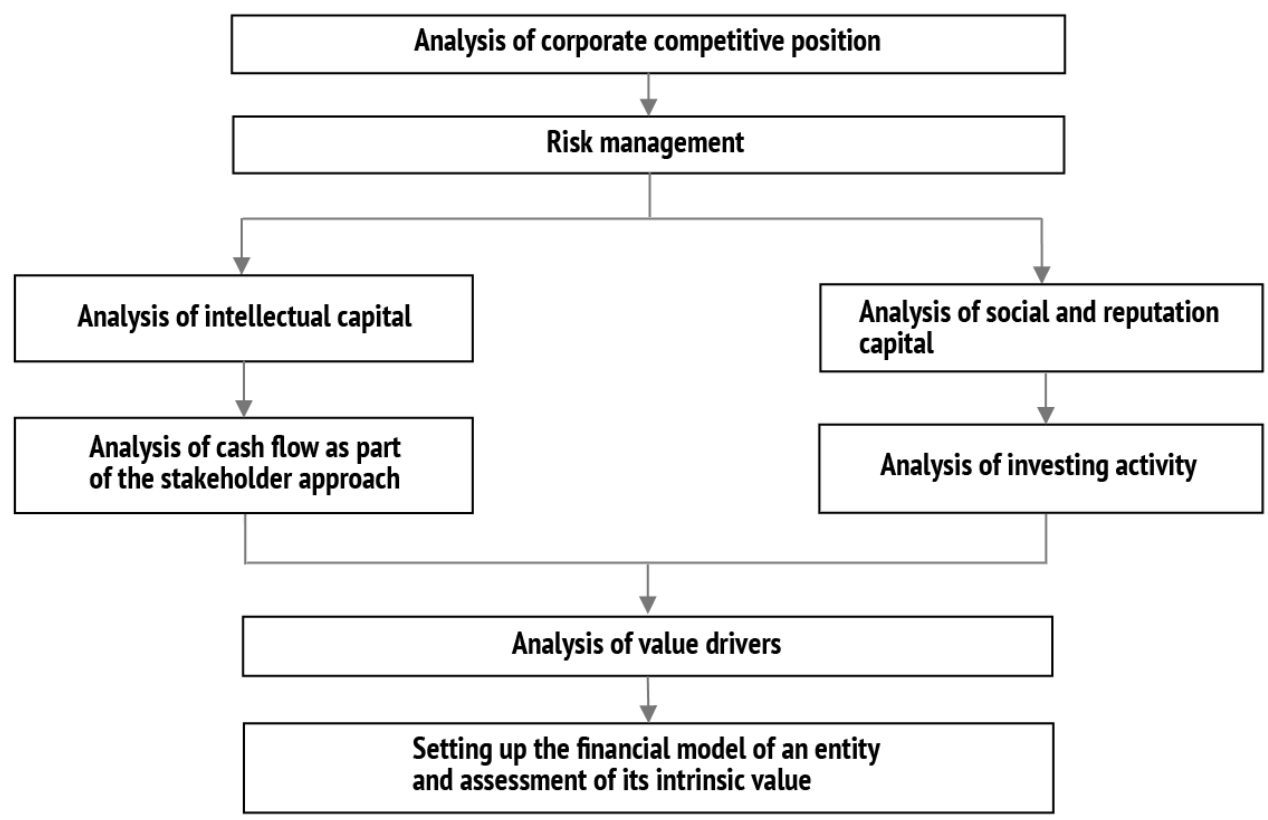

Source:Authoring

Figure 2 
Components of intellectual capital

\begin{tabular}{|l|l|l|l|}
\hline Intellectual capital \\
\hline Organizational wealth \\
Intellectual property
\end{tabular}

Source:Authoring

\section{Figure 3}

Components of social and reputation capital

\begin{tabular}{|c|c|}
\hline \multicolumn{2}{|c|}{ Social and reputation capital } \\
\hline & Supreme administrative authorities \\
\hline \multirow{3}{*}{$\begin{array}{l}\text { Corporate } \\
\text { component }\end{array}$} & Personnel: Rotation, professional level, \\
\hline & \\
\hline & $\begin{array}{l}\text { Buyers: Loyalty, satisfaction, margin, } \\
\text { market share, brand, trademarks }\end{array}$ \\
\hline \multirow[t]{3}{*}{ Market component } & Community of stakeholders: Stable feedback \\
\hline & $\begin{array}{l}\text { Competitors and business partners: Interaction, } \\
\text { competition intensity }\end{array}$ \\
\hline & $\begin{array}{l}\text { Shareholders: Stability of relationships with investors, } \\
\text { target return }\end{array}$ \\
\hline \multirow{2}{*}{$\begin{array}{l}\text { Financial } \\
\text { component }\end{array}$} & Creditors: Credit score, WACC \\
\hline & $\begin{array}{l}\text { State: Interaction with governmental authorities, administrative } \\
\text { resources, State aid, participation in governmental programs }\end{array}$ \\
\hline Social component & $\begin{array}{l}\text { Society: Participation in social programs, social investment, } \\
\text { public support level }\end{array}$ \\
\hline
\end{tabular}

Source:Authoring 


\section{References}

1. Reeves M., Levin S., Ueda D. [The Biology of Corporate Survival]. Harvard Business Review - Rossiya, 2016, March. URL: http://hbr-russia.ru/biznes-i-obshchestvo/fenomeny/a17381/ (In Russ.)

2. Ismail S., Malone M., Van Geest Y. Vzryvnoi rost: Pochemu eksponentsial'nye organizatsii v desyatki raz produktivnee vashei (i chto s etim delat') [Exponential Organizations: Why New Organizations are Ten Times Better, Faster, and Cheaper Than Yours (and What to Do about It)]. Moscow, Al'pina Didzhital Publ., 2014, $237 \mathrm{p}$.

3. Freeman R.E. Strategic Management: A Stakeholder Approach. Harpercollins College Div., 1984.

4. Post J.E., Preston L.E., Sachs S. Redefining the Corporation: Stakeholder Management and Organizational Wealth. Stanford University Press, 2002, 376 p.

5. Ivashkovskaya I.V. [Incorporating Stakeholder Approach into Financial Analysis: The Harmonized Firm]. Korporativnye finansy = Journal of Corporate Finance Research, 2011, vol. 5, no. 3.

URL: https://cfjournal.hse.ru/article/view/1583 (In Russ.)

6. Ivashkovskaya I.V. Finansovye izmereniya korporativnykh strategii. Steikkholderskii podkhod: monografiya [Financial measurements of corporate strategies. A stakeholder approach: a monograph]. Moscow, INFRA-M Publ., 2013, $320 \mathrm{p}$.

7. Mayer-Schönberger V., Cukier K. Bol'shie dannye. Revolyutsiya, kotoraya izmenit to, kak my zhivem, rabotaem $i$ myslim [Big Data. A Revolution That Will Transform How We Live, Work, and Think]. Moscow, Mann, Ivanov i Ferber Publ., 2014, 156 p.

8. Swan M. Blokchein: skhema novoi ekonomiki [Blockchain: Blueprint for a New Economy]. Moscow, Olimp-Biznes Publ., 2017, 103 p.

9. Cheremushkin S.V., Ponkrashkina G.A. [Cash Flow Return on Investment - CFROI]. Finansovyi menedzhment = Financial Management, 2009, no. 2, pp. 43-60. (In Russ.)

10. Shkaratan O.I., Inyasevskii S.A. Klassifikatsiya otraslei ekonomiki kak instrument analiza tendentsii ee transformatsii [Classification of economic sectors as a tool to analyze trends in its transformation]. Moscow, HSE Publ., 2007, 20 p.

11. Sonderegger P. Why Big Data Is the Capital Driving the Digital Age. URL: https://www.cmo.com.au/article/593641/why-big-data-capital-driving-digital-age/

12. Zaman Arif. Reputatsionnyi risk: upravlenie v tselyakh sozdaniya stoimosti [Reputation Risk: How to Manage for Value Creation]. Moscow, Olimp-Biznes Publ., 2008, 416 p.

13. Efimova O.V. [Analysis of sustainable development of the company: Stakeholder approach]. Ekonomicheskii analiz: teoriya i praktika = Economic Analysis: Theory and Practice, 2013, no. 45, pp. 41-51.

URL: https://cyberleninka.ru/article/n/analiz-ustoychivogo-razvitiya-kompanii-steykholderskiy-podhod (In Russ.)

14. Lyubushin N.P., Babicheva N.E., Lylov A.I. [Use of resource oriented economical analysis in estimation of stable development of managing subjects]. Vestnik Tambovskogo universiteta. Ser.: Gumanitarnye nauki = Tambov University Review. Series: Humanities, 2015, iss. 2, pp. 32-45. (In Russ.)

\section{Conflict-of-interest notification}

I, the author of this article, bindingly and explicitly declare of the partial and total lack of actual or potential conflict of interest with any other third party whatsoever, which may arise as a result of the publication of this article. This statement relates to the study, data collection and interpretation, writing and preparation of the article, and the decision to submit the manuscript for publication. 